\title{
Ovarian torsion within an incarcereted inguinal hernia; Ultrasound and color Doppler findings
}

\section{İnkarsere inguinal herni kesesi içerisinde yerleşen torsiyone over vakası: Ultrason ve renkli Doppler bulguları}

Sonay Aydin, Elif Ergüin, Erdem Fatihoğlu, Gamze Durhan, Punar Nercis Koşar

Ankara Training and Research Hospital, Department of Radiology, Turkey

Corresponding author: Sonay Aydin, Ankara Training and Research Hospital, Department of Radiology, Turkey

E-mail: sonaydin89@hotmail.com

Received/Accepted: August 13,2016/February 24, 2017

Conflict of interest: There is not a conflict of interest.

\section{SUMMARY}

Inguinal hernias can be seen in childhood approximately with a range between 0.8 and $4.4 \%$. In female patients, in $15 \%$ to $20 \%$ of cases there is an ovary with or without Fallopian tube in the inguinal hernia. In this paper, a case of 6 months old female patient presented with ovary containing inguinal hernia and ovarian torsion is presented. In cases of incarcerated ovary containing inguinal hernia prompt diagnosis and surgical reduction are very important to prevent ovarian torsion and ischemia. Ultrasound and/or Color Doppler Ultrasound play a crucial role in diagnosing hernia content as ovarian tissue and ovarian torsion, if happens.

Keywords: Inguinal hernia, ovary, torsion

\section{ÖZET}

Çocukluk çağında inguinal herni görülme sıklığı \%0.8 ile 4.4 arasında değişmektedir. Kadın hastalarda \%15-20 vakada inguinal herni kesesi içerisinde Fallop tüpü ile beraber ya da tek başına over bulunmaktadır. Vaka: Bu vaka raporunda 6 aylık bir kız çocuğunda görülen ve torsiyone over içeren inkarsere inguinal herni vakası görüntüleme bulguları ile sunulacaktır.Tartışma: Over içeren inkarsere inguinal herni vakalarında hızlı tanı ve acil tedavi , olası bir over torsiyonunu/nekrozunu önlemek açısından önemli rol oynamaktadır. Ultrason ve Renkli Doppler Ultrason herni kesesi içinde over varlığını göstermede ve olası bir torsiyona tanı koymada etkin ve önemli görüntüleme metodlarıdır. Anahtar sözcükler: İnguinal herni, over, torsiyon

\section{INTRODUCTION}

Inguinal hernias are seen in childhood at an approximate range of $0,8-4,4 \%$. It is more frequent in boys and infants, with the female/male ratio varying between $1 / 4$ and $1 / 10$. The incidence of indirect inguinal hernia in girls has been reported as $13,7 \%-23 \%^{1,2}$. In female patients, in $15 \%$ to $20 \%$ of cases there is an ovary with or without Fallopian tube in the inguinal hernia ${ }^{3}$. Ovarian torsion can occur within the inguinal hernia sac. In these cases, prompt diagnosis and treatment is vital to save the ovary before necrosis occurs ${ }^{2}$. In this paper, the ultrasonography (US) and color Doppler ultrasonography (CDUS) findings are presented of a case of an inguinal hernia containing a torsioned ovary.

\section{CASE REPORT}

A female infant aged 6 months, who had been born in the 40th gestational week at a weight of $3500 \mathrm{~g}$, was brought to the Pediatric Emergency Department with the complaint of a palpable mass in the left groin. The infant was very anxious and crying intensely. On physical examination, there was noticeable redness and a tender mass in the left 
inguinal region, located close to the labium majus. The patient was referred to the radiology department for US examination, the results of which revealed an indirect inguinal hernia sac measured $22 \times 20 \mathrm{~mm}$. The tissue material of the herniation was hyperechoic-heterogenous, nodular and had multiple millimetric hypoechoic-cystic structures (Figure 1,2). The cystic structures were evaluated as follicles and the herniated material was thought to be the left ovary. CDUS examination was also performed, and there was no vascularisation in the herniated left ovary (Figure 3 ). Thus, the case was diagnosed as a herniated and torsioned ovary. The infant was admitted for surgery, during which the left ovary was determined as necrotic and hemorrhagic. Both the left adnexa and the ovary were twisted $360^{\circ}$ in the longitudinal axis. A surgical procedure of left salpingo-oophorectomy was performed. Pathology report confirmed the presence of necrosis in the majority of the resected ovary.

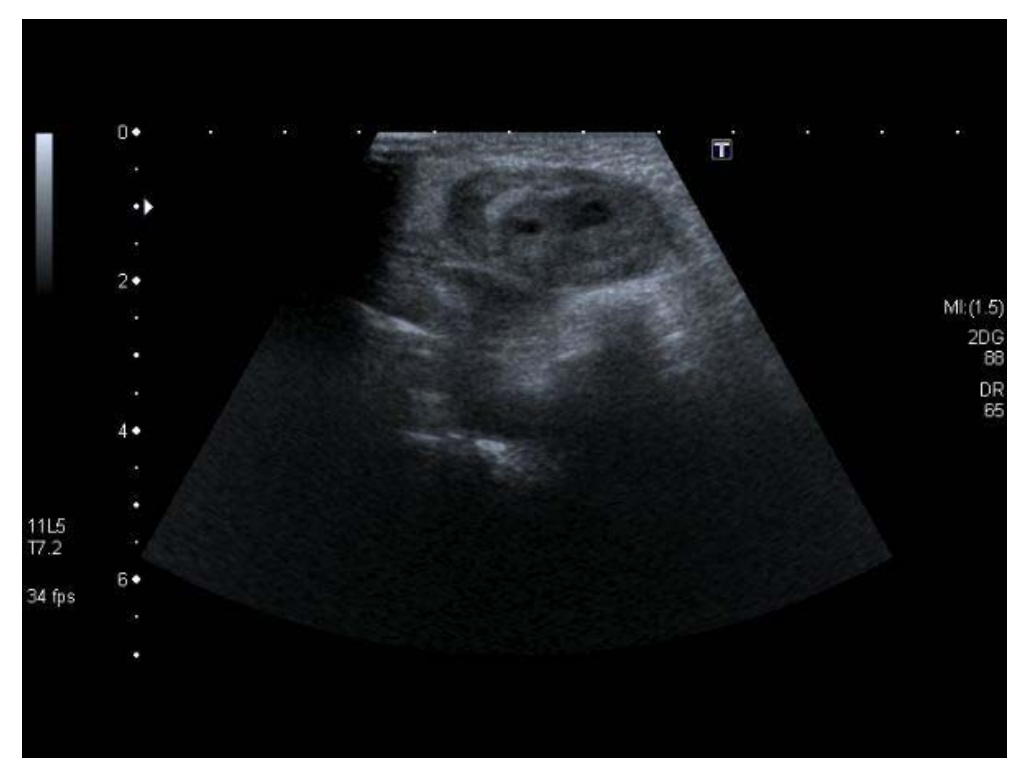

Figure 1. A nodular mass in left inguinal area containing small hypoechoic-cystic areas (arrows) (ovarian follicles) .

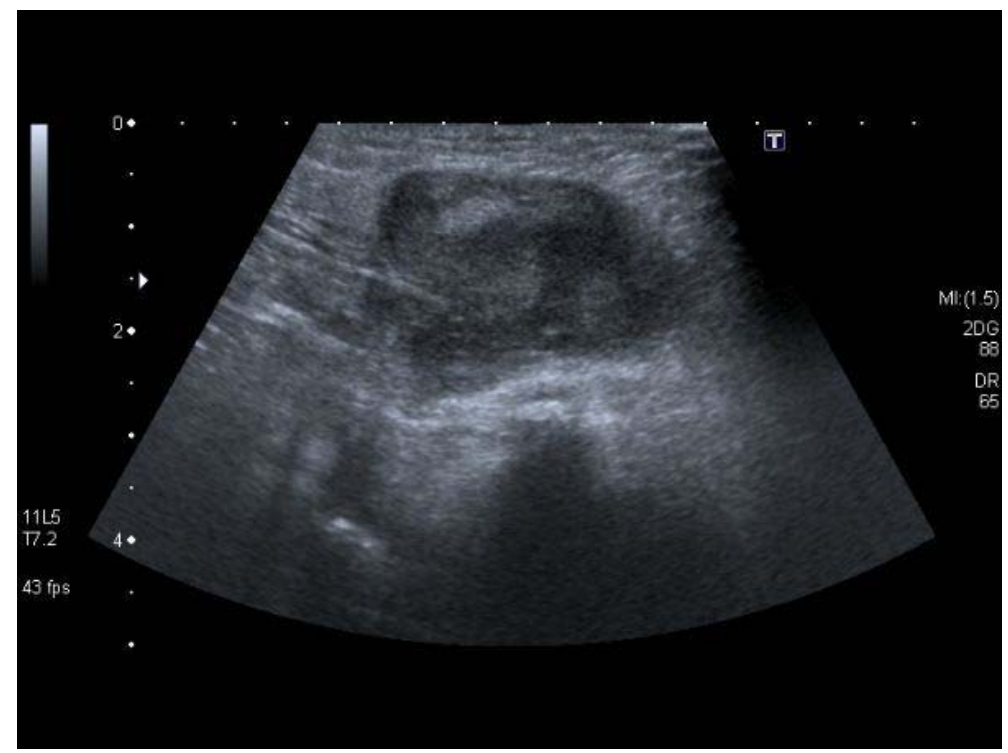

Figure 2. Herniated - torsioned ovarian tissue with heterogenous echo structure 


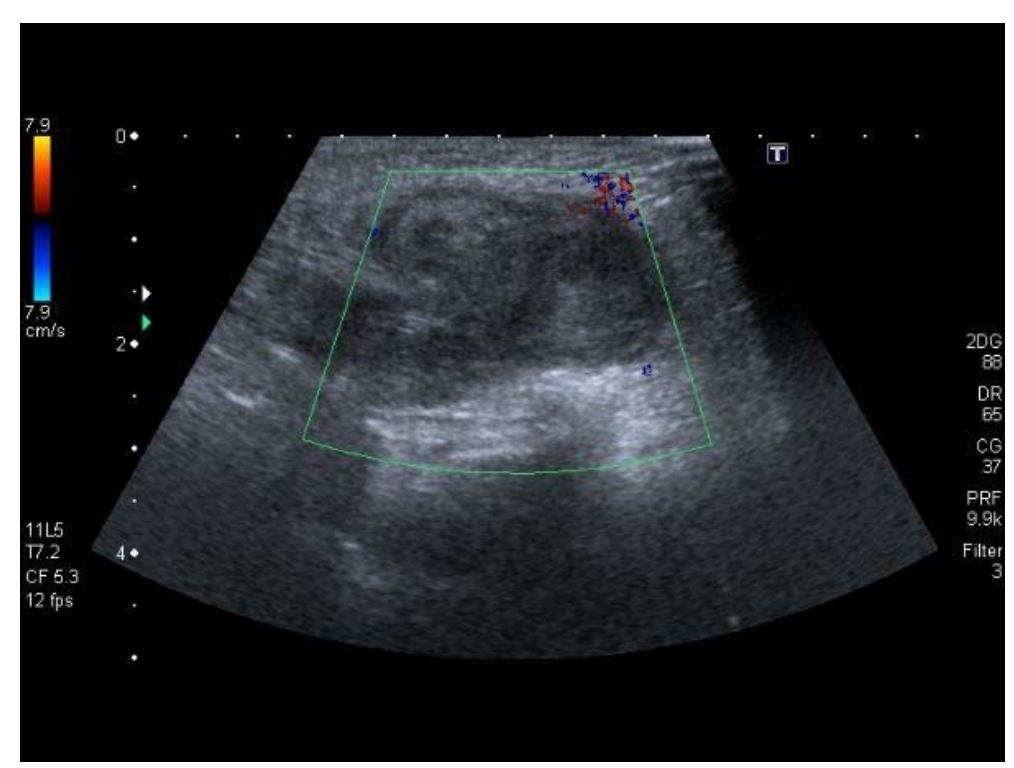

Figure 3. CDUS examination showing no vascularisation in the herniated ovary parenchyma.

\section{DISCUSSION}

The development of the inguinal canal is related to the two important anatomical structures of the gubernaculum testis and processus vaginalis. The gubernaculum is a ligamentous-like structure which attaches to the uterus next to the cornual level. The gubernaculum enlarges because of the increase in the hyaluronic acid content of the inguinal canal and as a result of enlargement of the inguinal canal, the scrotum / testis can pass through abdominal organs. The processus vaginalis is the series of invaginations that pass through the gubernaculum and spread out into the scrotum after emerging from the inner circle. In the female, the processus vaginalis is named the Nuck diverticulum and is much smaller than the male counterpart. This peritoneal sac generally fuses by the 32 nd gestational week. When the canal is not fully obliterated, inguinal hernias may develop. In these cases, bowel, fluid, the ovary, the fallopian tube, and the uterus, might all herniate into the canal. Certain lung problems, long-standing constipation and vigorous crying are some of the causes of herniation by increasing intra-abdominal pressure $^{2,4}$. It has been reported that in the pediatric population, inguinal hernias present as $68,1 \%$ on the right side, $23,4 \%$ on the left and $8,5 \%$ bilateral 5 . The most important complication of inguinal hernias in the pediatric population is incarceration at a frequency of $31 \%$. The ovaries tend to be the most frequent incarcerations in the hernia sac at a reported incidence of $43 \%{ }^{2}$. Hernias with an incarcerated ovary may cause torsion. Pressure on the incarcereted ovary may diminish the blood supply, especially in veins, thus causing venous congestion and subsequent ischemia and ultimately, necrosis. However, the actual risk for the blood supply is torsion of the ovarian pedicle. The risk of torsion is increased when the fallopian tubes are longer than usual as the ovaries become more mobile ${ }^{1,2}$.

US, not containing ionised radiation, is the best method for the evaluation of inguinal lesions, especially in children who are more vulnerable to the hazards of radiation. Furthermore, US provides detailed information about the nature of the mass and its relationship to adjacent structures. On US, the visualization of nodular masses which contain peripheral cysts is helpful for the characterization of hernia content as ovaries ${ }^{1,3}$.

Prompt diagnosis is crucial if the hernia contains an ovary, because incarceration of the ovary is prevalent and incarcerated ovaries are at risk of torsion. If torsion occurs, first venous and then the arterial flow of the ovary within the canal of Nuck is impaired. Ovarian torsion generally presents with symptoms such as severe irritability, abdominal pain, and vomiting. Gangrene and tissue necrosis may develop if the hernia is not reduced ${ }^{3}$. US findings of ovarian torsion can be summarised as an increase in the ovarian dimensions with a heterogeneous echo structure (probably due to hemorrhagic necrosis), and the presence of peripherally located multiple cysts. However, the presence of these findings alone is not enough for a definitive diagnosis of ovarian torsion. CDUS provides valuable information about the vascular structures at the ovarian pedicle and helps to determine if the ovarian parenchyma has suffered 
ischemia or not ${ }^{2}$. There are different views on the management of a sliding ovary herniation, but when there is incarceration of the ovary, urgent diagnosis with US/CDUS and early repair becomes the only solution to protect the ovary from necrosis $^{1}$. In addition to an ovary-containing hernia, other possible diagnoses for an inguinal/labial mass in the pediatric population are an enlarged lymph node ,a localized fluid collection in the inguinal canal (commonly called a hydrocele in the canal of Nuck) and a bowelcontaining hernia, ${ }^{6}$.

In conclusion, an ovary-containing hernia of the canal of Nuck is a rare etiology of inguinal masses. US and CDUS are very helpful in diagnosing an ovary-containing hernia and evaluating vascularisation of the herniated ovary. Hernias containing ovaries should be managed with prompt surgical reduction in order to prevent ovarian torsion and ischemia.

\section{REFERENCES}

1. Hyun PM, Jung AY, Lee Y, Yang I, Yang DH, Hwang JY. CT and US findings of ovarian torsion within an incarcerated inguinal hernia. Emerg Radiol 2015; 22: 91-4.

2. Kaya O, Esen K, Gulek B, Yilmaz C, Soker G, Onem $\mathrm{O}$. The inguinal herniation of the ovary in the newborn: ultrasound and color Doppler ultrasound findings. Case Rep Radiol 2014; 20 : 281.

3. Yang DM, Kim HC, Kim SW, Lim SJ, Park SJ, Lim JW. Ultrasonographic diagnosis of ovarycontaining hernias of the canal of Nuck. Ultrasonography 2014; 33: 178-83.

4. Laing FC, Townsend BA, Rodriguez JR. Ovary-containing hernia in a premature infant: sonographic diagnosis. J Ultrasound Med 2007; 26: 985-7.

5. Basrur GB. Bilateral inguinal hernias containing ovaries. Clinics and practice. 2015; 5: 708 .

6. Huang CS, Luo CC, Chao HC, Chu SM, Yu YJ, Yen JB. The presentation of asymptomatic palpable movable mass in female inguinal hernia. European journal of pediatrics. 2003; 162: 493-5. 